\title{
Kitosan Esasıı İlaç Taşıyıcı Sistem Üretimi ve In vitro Performansının Belirlenmesi
}

\author{
Yeliz Erşan ${ }^{1}$, Sakip Önder ${ }^{2 *}$ \\ ${ }^{1}$ Yıldız Teknik Üniversitesi, Elektrik Elektronik Fakültesi, Biyomedikal Mühendisliği Bölümü, İstanbul, Türkiye, (ORCID: 0000-0003-0104-7807), \\ yelize@yildiz.edu.tr \\ 2* Yıldız Teknik Üniversitesi, Elektrik Elektronik Fakültesi, Biyomedikal Mühendisliği Bölümü, İstanbul, Türkiye (ORCID: 0000-0001-8170-7929), \\ sonder@yildiz.edu.tr
}

(İlk Geliş Tarihi 17 Temmuz 2020 ve Kabul Tarihi 9 Ekim 2020)

(DOI: 10.31590 /ejosat.770863)

ATIF/REFERENCE: Erşan, Y. \& Önder, S. (2020). Kitosan Esaslı İlaç Taşıyıcı Sistem Üretimi ve In vitro Performansının Belirlenmesi. Avrupa Bilim ve Teknoloji Dergisi, (20), 270-279.

\section{$\ddot{O} \mathbf{z}$}

Sunulan çalışmanın amacı kemik dolgu malzemesi ve ilaç taşıma sistemi olarak kullanılabilecek kitosan mikro kürelerin üretimi, karakterizasyonu ve performansının in vitro olarak belirlenmesidir. Bu amaçla; kitosan esaslı mikro küreler emülsiyon çarpraz bağlama yöntemi ile üretilmiş olup, mikro kürelerin boyut, şekil ve ilaç yükleme verimliliklerine etki eden karıştırıcı hızı, çapraz bağlama ajanı gibi faktörler incelenmiştir. İlaç çalışmalarında kullanılmak üzere bakteriyel enfeksiyonların tedavisinde kullanılan antibiyotik ciprofloxacin tercih edilmiştir. Ayrıca, hazırlanan mikro kürelerin biyoaktivitelerini test etmek için yapay vücut sıvısı (SBF) hazırlanmış ve 3 hafta boyunca mikro küreler SBF içerisinde bekletilerek hidroksiapatit çökelmesi (HA) takip edilmiştir. SBF içerisine konulan mikro küreler haftalık olarak toplanmış, Taramalı Elektron Mikroskopu (SEM) ve Fourier Dönüşümlü Kızılötesi Spektroskopisi (FTIR) ile analiz edilmiştir. Işık Mikroskopu ve SEM analizlerine göre küre boyutları karıştırma hızı arttıkça azalmış ve 102,27 $\pm 34,58 \mu \mathrm{m}$ den 16,38 $\pm 3,26 \mu \mathrm{m}$ ye kadar düşmüştür. Düşük miktarda kullanılan çapraz bağlayacı ajan glutaraldehit (GA) $\left(\mathrm{NH}_{2}: \mathrm{CHO}, 10: 1 \mathrm{~mol}: \mathrm{mol}\right)$ ise küre şekillerinde bozukluğa neden olurken, yüksek miktarda GA kullanımı $\left(\mathrm{NH}_{2}: \mathrm{CHO}_{1}\right.$ 1:10 mol:mol) kürelerin şeklinde iyileşmeye, küre boyutunda ve ilaç yükleme verimliliğininde azalmaya, ilaç salım hızında ise yavaşlamaya neden olmuştur. SBF ile inkübe edilen mikro kürelerin SEM görüntülerine göre HA yapıları 1. haftadan sonra yüzeylerde birikmeye

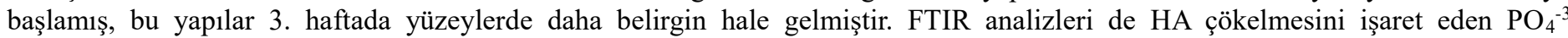
gruplarının 3. haftada daha belirgin olduğunu göstermiştir. Bu sonuçlara göre antibiyotik ciprofloxacin yüklü kitosan mikro küreler emülsiyon çapraz bağlama yöntemi ile başarılı bir şekilde üretilmiş olup, karıştırma hızı ve çapraz bağlayıcı ajanı GA miktarlarının mikro küre boyut, şekil ve salım profillerine etkisi ortaya konmuştur. Biyoktivite testlerinde kitosan mikro kürelerin, osteoentegrasyonu arttırma potansiyelinin olduğu gösterilmiştir. Dolayısıyla kitosan mikro küreler, kemik doku hasarlarında lokal olarak biyomoleküllerin salımını yapabilen dolgu malzemesi olarak veya implant malzemelerin yüzeylerinin modifikasyonunda kullanılabilir.

\section{Synthesis of Chitosan Based Drug Delivery System and Evaluation Its Performance In Vitro}

\begin{abstract}
The aim of the present study is to synthesize, characterize chitosan microspheres that can be used as bone-filling material and drug carrier system, and to evaluate its performance in vitro. For this purpose; chitosan-based microspheres were synthesized by the emulsion cross-linking method and factors such as stirring rate and cross-linker that may affect the size, shape, and drug loading efficiency of microspheres were examined. Antibiotic ciprofloxacin that is used in the treatment of bacterial infection was preferred for drug studies. Furthermore, simulated body fluid (SBF) was prepared to determine the bioactivity of the microspheres, and hydroxyapatite (HA) precipitation on microspheres was followed for 3 weeks in SBF. Microspheres were collected from SBF weekly
\end{abstract}

* Sorumlu Yazar: sonder@yildiz.edu.tr 
and characterized using light microscopy, Scanning Electron Microscopy (SEM), and Fourier Transform Infrared Spectroscopy (FTIR). According to the light microscope and SEM analysis, the sphere dimensions decreased as the stirring rate increased and decreased from $102,27 \pm 34,58 \mu \mathrm{m}$ to $16,38 \pm 3,26 \mu \mathrm{m}$. Low amount of cross-linking agent ( glutaraldehyde $(\mathrm{GA})$ ), $\left(\mathrm{NH}_{2}: \mathrm{CHO}_{10}\right.$ : 1 mol: mol) caused distortion in the shape of microspheres, while the high amount of $\mathrm{GA}\left(\mathrm{NH}_{2}\right.$ : $\mathrm{CHO}$, 1:10 mol: mol) caused smooth microspheres, a reduction in the size and drug loading efficiency, and a slowdown in the drug release rate. According to the SEM images of the microspheres incubated with SBF, HA structures began to precipitate on the surfaces after the first week, and these structures became more pronounced in the third week. $\mathrm{PO}_{4}{ }^{-3}$ groups attributed to HA precipitation in FTIR spectrum were more obvious at week 3. In conclusion; antibiotic ciprofloxacin loaded chitosan microspheres were synthesized successfully by the emulsion crosslinking method, and the effect of stirring rate, crosslinking agent GA amounts on microsphere size, shape, and release profiles were demonstrated. Enhanced HA precipitation was shown on chitosan microspheres in bioactivity tests. Hence, chitosan microspheres may be used as bone-filling material that can release biomolecules to damaged sites locally, or as coating to modify the surfaces of implant materials.

Keywords: Chitosan, Drug Release, Bioactivity.

\section{Giriș}

İlaç taşıma sistemleri; belirli zaman aralıklarında yerel veya sistemik olarak uzun vadeli bir tedavi için önceden belirlenmiş ve tekrarlanabilir kontrollü ilaç salınımını sağlamaktadır (Nathan \& Scobell, 2012). Geleneksel yöntemde ilaç bir seferde ve yüksek dozda verilir ve doz birkaç saat veya bir gün sonra tekrarlanmalıdır. Bu yöntem ekonomik değildir ve zararlı yan etkilere sahiptir (Nanjwade vd., 2011). Kontrollü ilaç salım sistemlerinin amacı, ilaç tedavisinin performansını arttırmaktır. $\mathrm{Bu}$ mekanizma terapötik aktiviteyi arttırır ve doz frekansı, doz azaltımı ve tedavi sırasında doz aşımı nedeniyle toksisiteyi düşürerek yan etkileri azaltır. Kontrollü ilaç salım sistemi, kan plazmasında sabit bir ilaç konsantrasyonu seviyesi sağlar. İlaç konsantrasyonu seviyesi sabit değilse, ilaç normal seviyenin altına düşer veya toksik seviyenin üzerine çıkar. $\mathrm{Bu}$ durum hastada istenmeyen yan etkilere neden olabilir.

Kontrollü ilaç taşıma sistemi bir polimerin bir ilaç ya da başka bir aktif ajan ile birleştirilmesiyle üretilir. İlaç taşıma sistemlerinde kullanılan polimerler, toksik olmayan, alerjik olmayan, yüksek saflıkta ve tekrarlanabilir olmalı, in vivo koşullarda biyolojik olarak parçalanabilmeli ve parçalanma işlemi sonrası oluşan yapılar metabolizmada kullanılabilmelidir (Seyfoddin \& Al-Kassas, 2011). Biyomalzeme olarak kullanılan biyolojik olarak bozunabilir polimerler doğal veya sentetik olabilir. Sentetik polimerler, bireysel ihtiyaçlara göre uyarlanabildiği için daha fazla esneklik sağlar ve doğal polimerler uygun, ucuz ve kimyasal olarak modifiye edilebilir (Kalia \& Avérous, 2011). Kitosan toksik olmamas1, biyouyumluluğu, biyolojik bozunabilirliği, düşük allerjenite ve muko-yapışması nedeniyle tıbbi uygulamalar alanında önemli bir role sahiptir (Di Martino vd., 2005; Khor \& Lim, 2003; Şenel \& McClure, 2004). Özellikle yüksek biyouyumluğu ve biyolojik olarak parçalanabilirliği tıbbi uygulamalar için önemli firsatlar sağlamaktadır. Kitosanın biyolojik olarak parçalanabilir özelliği ilaç taşıma sistemleri için önemli bir avantajdır (Dash vd., 2011). Memeli vücudunda kolondaki lizozim ve bakteriyel enzimler, metabolik aktivitelerde kitosanı parçalayabilir (Dias vd., 2013). Kitosan toksik olmaması nedeniyle de FDA tarafindan Japonya, İtalya ve Finlandiya'da diyet uygulaması ve yara pansumanında kullanılmak üzere onaylanmıştır (Illum, 1998; Thanou vd., 2001; Wedmore vd., 2006).

Mikro küre esaslı ilaç taşıma sistemleri ilaçların çeşitli polimerlerle kombinasyonu/formülasyonu yoluyla spesifik uygulama alanına uyarlanmasını sağlar. Mikro küre esaslı sistemler biyoaktif maddelerin salınmasını kontrol eder ve aktif bileşenlerin ömrünü uzatabilir. Kitosan esaslı mikro küreler, ilaçların kontrollü salınımı için yaygın olarak kullanılan ilaç taşıma sistemleridir. Anti-hipertansif ajanlar, anti-kanser ajanları, anti-inflamatuar ajanlar, proteinler, peptit ilaçlar ve aşıların kitosan esaslı mikro kürelerden salımı literatürde çalışılmaktadır (Sinha vd., 2004). Kitosan esaslı mikro küreler püskürterek kurutma, eleme yöntemi, koaservasyon/çökeltme, emülsiyon çapraz bağlama, iyonik jelleştirme vb. gibi çeşitli tekniklerle üretilebilmektedir (Agnihotri vd., 2004). Emülsiyon çapraz bağlama yönteminde kitosanın reaktif fonksiyonel amino grubunun çapraz bağlayıcı maddenin mevcut reaktif gruplarıyla çapraz bağlanmasından yararlanmaktadır. Bu yöntemde, yağ içinde su emülsiyonu, kitosan sulu çözeltisinin yağ fazında emülsiyon haline getirilmesi ile hazırlanır. Sulu damlacıkları stabilize etmek için uygun bir yüzey etkin maddesi kullanılır. Daha sonra uygun çapraz bağlayıcı ortama eklenerek damlacıkların (mikro kürelerin) mekanik özelliklerinin iyileştirilmesi sağlanır. Son işlem olarak mikro küreler filtrelenerek yıkanır ve kuruma işlemine bırakılır (Akbuğa \& Durmaz, 1994).

İlaç taşıma sistemlerinin üretilmesinde kullanılan polimerlerin yapısında bulunan reaktif gruplar sadece çapraz bağlayıcı maddelerin bağlanması için değil, belirli bir organa/dokuya hedeflenmiş ilaç taşıma sistemlerinin ve polimerik kompozit yapılarının üretilmesi içinde oldukça önemlidir (Bhattacharya vd., 2016; Hreczuk-Hirst vd., 2001; Mattu vd., 2016). Örneğin, Depan vd., organik-inorganik hibrid 3B yapı üretmek amaciyla kitosan ve nano hidroksiapatit (nHA) yapılarını kullanmışlardır (Depan vd., 2011). Kitosanın yapısında bulunan $-\mathrm{NH}_{2}$ gruplarına propilenoksit bağlanmış, nHA yapısı etilen glikol ile fonksiyonel hale getirilmiş ve doku mühendisliği uygulamalarında kullanılmak üzere mekanik özellikleri, fiziksel-kimyasal özellikleri, biyouyumluluğu arttırılmış hibrid yapılar üretilmiştir. Aynı şekillde, Zhe vd, ise PLGA esaslı mikro kürelerin yüzeyinde nano hidroksiapatit büyütülebildiğini göstermişlerdir (Zhe vd., 2011). Bu çalışmada polimerin yapısında bulunan $-\mathrm{COOH}$ gruplarının $\mathrm{Ca}^{2+}$ bağlama özelliğinden yararlanılmış ve PLGA yüzeyleri nHA yapıları ile kaplanmıştır.

Hidroksiapatit (HA) $\left(\mathrm{Ca}_{10}\left(\mathrm{PO}_{4}\right)(\mathrm{OH})_{2}\right)$ doğal bir mineral olup diş minesi, dentin, kemik gibi dokuların yapısında yer almaktadır. Sentetik ve doğal seramik malzemelerin yapı iskelesi olarak kullanılma potansiyelinin keşfinden sonra bu malzemeler özellikle kemik doku mühendisliği alanında kendilerine geniş bir uygulama alanı bulmuşlardır (Burg vd., 2000). Bunun temel sebebi seramiklerin kemiğin doğal inorganik kısmına çok benzemeleri, yüksek biyouyumluluğu ve osteokondaktif özelliğinin olmasıdır (Leukers vd., 2005; Teixeira vd., 2009). Kemik-implant ara yüzeyinde çok kuvvetli bağlar 
oluşturabilmektedir (Onder vd., 2015) ve kemiğin bu yüzeyde büyüyebilmesini hızlandırmaktadır. HA gözenekli yapısı sayesinde hücrelerin, gözeneklerin içine doğru büyümesine izin verir ve dokuların implante nüfuz etmesini sağlar. Ayrıca HA'nın yapısındaki gözenekler, kanallar sistemi gibi davranıp, kemik yapıya kanın ve diğer önemli vücut sıvılarının ulaşmasını sağlar (Pasinli \& Aksoy, 2010). Yapılan çalışmalarda HA yapısı ile yüzeyi modifiye edilmiş titanyum malzemelerde, yüzeyi modifiye edilmeyenlere göre osteoblast hücrelerin tutunma, büyüme ve farklılaşma kabiliyetlerinin arttığı görülmüştür (Lee vd., 2009; Liu vd., 2011). Bu seramikler yüksek kırılganlıkları yüzünden kemiklerin mekanik özelliklerini taşımamaktadır ve bu yüzden doğrudan sert doku implantı olarak kullanılamazlar. Fakat bahsedilen özelliklerinden ötürü metal implant malzemeleri için kaplama malzemesi olarak, tek başlarına veya farklı biyomalzemeler ile karıştırılarak kemik yaralanmalarının tedavisinde dolgu malzemesi olarak kullanılabilmektedirler.

Kontrollü ilaç sistemlerinin ve HA yapısının sırasıyla hastalıkların tedavisi ve sert doku uygulamalarındaki pozitif etkileri göz önüne alındığında, HA ve kitosan esaslı ilaç taşıma sisteminden oluşan hibrit bir yapının hasarlı kemik dokuların tedavisine önemli katkılar sunacağı düşünülmektedir. Dolayısıyla bu çalışmada; (i) ilaç taşıma sistemi/kemik dolgu malzemesi olarak kullanılabilecek ve kontrollü salım yapabilecek kitosan mikro kürelerin üretimi ve karakterizasyonu, (ii) $\mathrm{SBF}$ içerisinde kitosan mikrokürelerin yüzeylerinde $\mathrm{HA}$ büyümesinin tespiti çalışılacaktır. Bu amaçla, kitosan esaslı miro küreler emülsiyon çarpraz bağlama yöntemi ile üretilecek olup, mikro kürelerin boyut, şekil ve ilaç yükleme verimliliklerine etki eden karıştırıcı hızı, çapraz bağlama ajanı gibi faktörler incelenecektir. Bahsedilen faktörlerin etkisi 1 şı mikroskopu, SEM ve ilaç salım çalışmaları ile tespit edilecektir. Mikro kürelerin biyoaktive testleri ise SBF içerisinde yapılacak olup, yüzeylerdeki HA büyümesi SEM, Enerji Dağılımı Spektrometresi (EDS) ve FTIR ile takip edilecektir.

\section{Materyal ve Metot}

\subsection{Materyal}

Çalışma kapsamında kullanılan mineral yağı, kitosan (deasetilasyon oran $1=\% 96,50494$ Sigma), gluteraldehit (GA), ciprofloxacin, $\mathrm{NaCI}, \mathrm{NaHCO}_{3}, \mathrm{KCl}, \mathrm{K}_{2} \mathrm{HPO}_{4} .3 \mathrm{H}_{2} \mathrm{O}$, $\mathrm{MgCl}_{2} \cdot 6 \mathrm{H}_{2} \mathrm{O}, \mathrm{HCl}, \mathrm{CaCl}_{2}, \mathrm{Na}_{2} \mathrm{SO}_{4}$ ve $\left(\mathrm{CH}_{2} \mathrm{OH}\right)_{3} \mathrm{CNH}_{2}$ Sigma Aldrich' ten temin edildi.

\subsection{Metot}

\subsubsection{Kitosan Mikrokürelerin Üretilmesi}

Mikro küre üretiminde emülsiyon çapraz bağlama yöntemi kullanıldı. Bunun için $50 \mathrm{ml}$ mineral yağı içerisine $1000 \mu \mathrm{l}$ span 80 eklenerek oda sıcaklığında mekanik karıştırıcı ile 10 dakika karıştırıldı. 0,1 gr kitosan asetik asit $(0.1 \mathrm{M})$ içerisinde çözdürülerek \%2'lik kitosan çözeltisi hazırlandı $(5 \mathrm{ml})$. Hazırlanan polimer solüsyonu, şırınga yardımıyla sabit bir hızda yağ karışımına damlatılarak eklendi ve 30 dakika boyunca 500 rpm hızla karıştırıldı. Çapraz bağlayıcı ajanı, (125 $\mu 1) 25 \%$ Gluteraldehit (GA) eklendi ve 1 saat karıştırıldı. Karışım $60{ }^{\circ} \mathrm{C}$ de 1,5 saat inkübe edilerek çözücünün ortamdan uzaklaştırılması ve kürelerin çökmesi sağlandı. Kürelerden yağın uzaklaştırılması için küreler hekzan ile $5 \mathrm{dk}$ boyunca 3 defa yıkandı. Yıkama işlemi için santrifüj (4000 rpm, 5 dk) kullanıldı. Yıkanan küreler kuruması için 1 gün $37{ }^{\circ} \mathrm{C}$ de bekletildi. Kuruyan küreler, kullanılana kadar desikatörde muhafaza edildi.

\subsubsection{GA Miktarının Mikro Küre Boyutu Üzerine Etkisinin İncelenmesi}

Kitosan mikro kürelerin yüzeylerinde bulunan $-\mathrm{NH}_{2}$ grupları GA tarafından çapraz bağlama işlemi için kullanılmaktadır. $\mathrm{Bu}$ sebeple çapraz bağlama işleminin küre boyutları ve salım profilleri üzerine etkisinin incelenmesi için küre üretimi esnasında farklı GA miktarı kullanıldı. Ortama eklenen kitosanın yapısındaki $-\mathrm{NH}_{2}$ gruplarının ve GA yapısındaki $-\mathrm{COOH}$ gruplarının oranları $\mathrm{NH}_{2}: \mathrm{COOH}$, 10:1,1:1,1:10 mol:mol olacak şekilde ayarlandı (Filipkowska \& Józwiak, 2013) ve bu hesaba göre küre yapımı sırasında ortama sırasıyla 40, 400 ve $4000 \mu \mathrm{l}$ (\%25'lik) GA çapraz bağlayıcı ilave edildi. Elde edilen kürelerin şekil ve boyutunu analiz etmek için 1şık mikroskobu ve SEM kullanıldı.

\subsubsection{Karıștırma Hızının Mikro Küre Boyutu Üzerine Etkisinin İncelenmesi}

Karıştırma hızının mikro küre boyutu üzerine etkisini belirlemek için, yağ/sıvı karışımı farklı karıştırma (200-600 rpm) hızlarında karıştırıldı. Küre boyutlarını analiz etmek için yine 1şık mikroskobu ve SEM kullanıldı.

\subsubsection{GA Miktarının İlaç Yükleme Verimliliği ve İlaç Salımı Üzerine Etkisinin İncelenmesi}

İlaç mikro küre üretiminde kullanılacak polimer solüsyonu içerisinde çözdürüldü ve küre oluşumu sırasında tutuklama işlemi gerçekleştirildi. Küre üretimi sırasında, \%2'lik kitosan solüsyonu $(5 \mathrm{ml})$ içerisine $500 \mu \mathrm{g} / \mathrm{ml}$ derişiminde $1 \mathrm{ml}$ ilaç (ciprofloxacin) eklenerek karıştırıldı (500 rpm). İlaçlı polimer solüsyonu yağ karışımına eklenerek ilaç yüklü mikro küreler üretildi. $\mathrm{Bu}$ işlem 40, 400 ve $4000 \mu \mathrm{l} \mathrm{GA}$ miktarları için tekrarlandı. Yağ fazında, yüklenmeyen ilaç miktarının analizi zor olduğundan ilaç yükleme verimi ilaç salım profili elde edildikten sonra hesaplandi.

İlaç salım profillerinin belirlenmesi için 40, 400 ve $4000 \mu \mathrm{l}$ GA içeren mikro kürelerden 250'şer mg alınarak 15 ml'lik falkon tüplere yerleştirildi. Her bir falkon tüpünün içerisine sıcaklığ $137^{\circ} \mathrm{C}$ olan $3 \mathrm{ml}$ PBS $(0.1 \mathrm{M})$ çözeltisi eklendi ve bu tüpler $37^{\circ} \mathrm{C}$ de çalkalayıcı üzerinde $(100 \mathrm{rpm})$ salıma bırakıldı. $\mathrm{Bu}$ denemeler üçlü setler halinde yapıldı. Numune toplama aşamasında falkon tüplere $4000 \mathrm{rpm}$ de 3 dakika süren santrifüj işlemi uygulandı ve dikkatli bir şekilde örnekler üst fazdan topland1. Numunelerin alınmasından sonra ortama tekrar PBS eklenerek örnekler $37^{\circ} \mathrm{C}$ muhafaza edildi. $500 \mu \mathrm{g}$ ilaç eklenerek hazırlanan mikro kürelerden salımı yapılan ilaç miktarı 2-400 saat aralığında toplanan örnekler üzerinde çalışıldı. Toplanan örneklerdeki ilaç miktarları kalibrasyon eğrisi kullanılarak hesaplandı. Kalibrasyon eğrisi bilinen ilaç miktarlarına karşılık UV-VIS spektrofotometre kullanılarak $278 \mathrm{~nm}$ 'de okumalar yapılarak çizildi. Farklı miktarda çapraz bağlayıcı kullanılan çalışmalarına ait sonuçların salım profilleri elde edildikten sonra yükleme verimliliği şu şekilde hesaplanmıştır: 
ilaç yükleme verimliliğgi (\%)

$$
=\frac{\text { salımı yapılan ilaç miktar } \iota}{\text { eklenen ilaç miktar } \iota} \times 100
$$

\subsubsection{Mikro Kürelerin Biyoaktivite Çalışmaları}

Mikro kürelerin biyoaktiviteleri yapay vücut sıvısı (SBF,1X) ile değerlendirilmiştir. SBF hazırlanmasında daha önceki çalışmada kullanmış olduğumuz prosedür uygulanmıştır (Onder vd., 2013). Kısaca, $40 \mathrm{ml} 1 \mathrm{X}$ SBF çözeltisi hazırlamak için distile su içerisine surasıyla 0,319 gr $\mathrm{NaCI}, 0,013$ gr $\mathrm{NaHCO}_{3}$, 0,009 gr KCl, 0,009 gr $\mathrm{K}_{2} \mathrm{HPO}_{4} .3 \mathrm{H}_{2} \mathrm{O}, 0,01$ gr $\mathrm{MgCl}_{2} \cdot 6 \mathrm{H}_{2} \mathrm{O}$, $1,48 \mathrm{ml} \mathrm{HCl}(1 \mathrm{M}), 0,01 \mathrm{gr} \mathrm{CaCl}_{2}, 0,003 \mathrm{gr} \mathrm{Na}_{2} \mathrm{SO}_{4}$ ve $0,24 \mathrm{gr}$ $\left(\mathrm{CH}_{2} \mathrm{OH}\right)_{3} \mathrm{CNH}_{2}$ eklendi ve $\mathrm{pH}$ değeri $37{ }^{\circ} \mathrm{C}$ de 7.4 olacak şekilde ayarlandı. $\mathrm{pH}$ değerlerinin ayarlanmasında $1 \mathrm{M}$ HCI veya
$1 \mathrm{M} \mathrm{NaOH}$ çözeltileri kullanıldı. SBF hazırlandıktan sonra 100 mg küre $5 \mathrm{ml} \mathrm{SBF}$ içerisinde $37{ }^{\circ} \mathrm{C}$ çalkalayıcıda 3 hafta boyunca inkübasyona bırakıldı. SBF çözeltisi 2 günde bir yenisi ile değiştirildi ve haftada bir örneklerden numuneler alınarak SEM, EDS ve FTIR analizleri yapıldı.

\section{Araştırma Sonuçları ve Tartışma}

\subsection{GA Miktarının Mikro Küre Boyutu Üzerine Etkisi}

$40 \mu$ l'lik GA kullanımında elde edilen kürelerin 1 şık mikroskopu görüntülerinde özellikle kürelerin daha fazla miktarda birbirine yapıştığ 1 ve bozulmuş küre yapılarının varlığı gözlemlendi (Şekil 1). Bunun bir sebebi ortamda yeterince çapraz bağlayıcı olmaması ve aynı çapraz bağlayıcının farklı

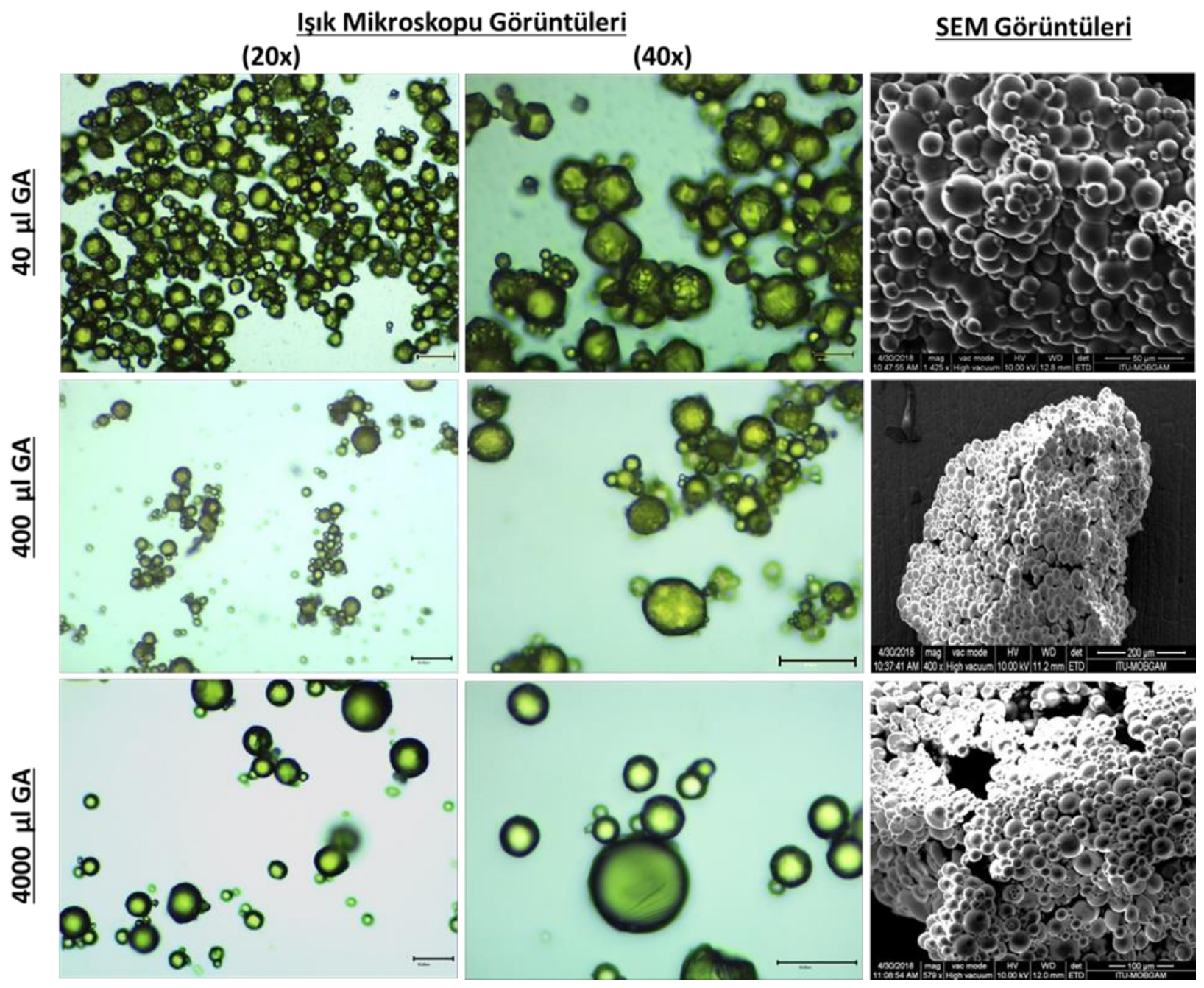

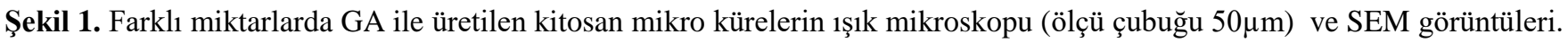

kürelerin yüzeylerinde bulunan $-\mathrm{NH}_{2}$ grupları ile bağ kurması olabilir. 400 ve $4000 \mu \mathrm{l}$ çapraz bağlayıcı kullanımında ise mikro kürelerin boyutlarının daha homojen dağıldığı ve şekil olarak daha küresel forma sahip olduğu görülmektedir. SEM analizleri de 1 şı mikroskopu analizlerini desteklemektedir.

Elde edilen kürelerin çaplarının belirlenmesi için 1 şı mikroskopu altında farklı GA varlığında üretilmiş ve farklı 

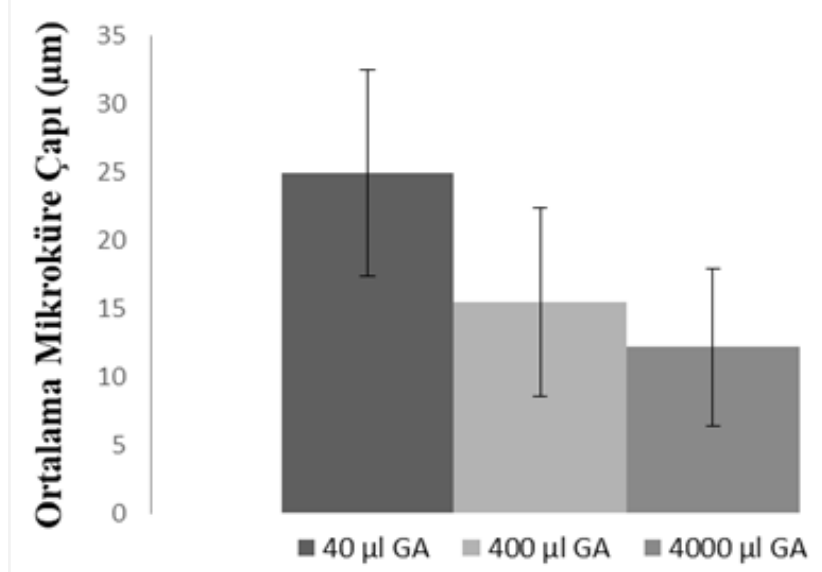

Şekil 2. Farklı GA miktarları kullanılarak üretilen mikro kürelerin boyut analizi.

boyutlara sahip küreler üzerinde boyut analizleri yapılmıştır (Farklı boyutlara sahip seçilmiş 100 adet mikro kürenin çap1 ölçülmüştür). $\mathrm{Bu}$ analize göre $40 \mu \mathrm{l} \mathrm{GA}$ ile üretilen mikro kürelerin ortalama çap1 $25 \pm 7,5 \mu \mathrm{m}, 400 \mu \mathrm{l}$ GA ile üretilen mikro mikro kürelerin ortalama çapı $15,5 \pm 6,9 \mu \mathrm{m}$ ve $4000 \mu \mathrm{l}$ GA ile üretilen mikro kürelerin ortalama çap1 $12,2 \pm 5,8 \mu \mathrm{m}$ 'dir (Şekil 2).

Dolayısıyla GA miktarındaki artış küre boyutlarında küçülmeye neden olmaktadır. GA çapraz bağlayıcısının kitosan kürelerin yapısında bulunan serbest $-\mathrm{NH}_{2}$ gruplar1 ile bağ yaptığı göz önüne alınırsa, GA miktarındaki artış ile küre yüzeylerinde serbest $-\mathrm{NH}_{2}$ gruplarının miktarında azalma olması, daha sağlam ve küreye benzer yapıların oluşması beklenmekteydi. Kürelerin çaplarında meydana gelen azalma bu görüşü desteklemektedir. Ayrıca 400 ve $4000 \mu$ l GA kullanılarak oluşturulan kürelerin boyutları arasındaki farkın $40 \mu \mathrm{l}$ ve $400 \mu \mathrm{l}$ GA kullanılarak oluşturulan kürelerin boyutları arasındaki farktan daha az olması, $400 \mu$ l çapraz bağlayıcının kullanıldığı yüzeylerde çapraz bağlama işleminden sonra küre yüzeylerinde serbest $-\mathrm{NH}_{2}$ gruplarının bulunduğunu fakat miktarında bir azalmanın olduğunu göstermektedir.
Kitosan yüzeyinde bulunan amino grupları $\mathrm{pH}<6.5$ değerinde proton kazanmakta olup (Ali \& Ahmed, 2018), yüzeylerde hidroksiapatit büyümesi için çekirdeklenme merkezi oluşturma potansiyeline sahiptir. Mikro küre yüzeylerinde daha fazla $-\mathrm{NH}_{2}$ grubuna sahip olunmas1 durumunda mikro kürelerin biyoaktivitelerinin artmas1 sağlanabilir. $\mathrm{Bu}$ nedenle daha homojen küre boyutlarının üretilmesine olanak sağlayan $400 \mu \mathrm{l}$ GA bundan sonraki küre çalışmalarında kullanılacak en uygun çapraz bağlayıcı miktarı olarak belirlenmiştir.

\subsection{Karıştırma Hızının Mikro Küre Boyutu Üzerine Etkisi}

Iş1k mikroskopu analizlerine göre karıştırma hızı arttıkça oluşan küre boyutları küçüldü ( Şekil 3). Farklı karıştırma hızlarının kullanıldığı üretim işlemlerinin sonunda elde edilen farklı boyutlardaki mikro küreler üzerinde yapılan boyut analizinde (Farklı boyutlara sahip seçilmiş 100 adet mikro kürenin çap1 ölçülmüştür) küre boyutlarının 200 rpm'de $102,27 \pm 34,58 \mu \mathrm{m}, 300 \mathrm{rpm}$ 'de $61,03 \pm 20,59 \mu \mathrm{m}, 400$ rpm'de 48,81 $\pm 11,41 \mu \mathrm{m}, 500 \mathrm{rpm}$ 'de $21,86 \pm 4,34 \mu \mathrm{m}$ ve 600 rpm'de 16,38 $\pm 3,26 \mu \mathrm{m}$ olduğu görüldü.

Dolayısıyla karıştırma hızındaki artışın da küre boyutlarında azalmaya neden olduğu ortaya konuldu. 200-600 rpm karıştırma hızı aralığında ortalama 15-100 $\mu \mathrm{m}$ çapında mikro kürelerin üretiminin mümkün olduğu gösterilmiştir. Fakat düşük karıştırma hızlarında küre boyutlarındaki farklılık artış göstermekte ve homojen boyutta küre üretimi zorlaşmaktadır. $\mathrm{Bu}$ nedenle çalışmalara $500 \mathrm{rpm}$ karıştırma hızı ile devam edilmiştir.

\subsection{GA Miktarının İlaç Yükleme Verimliliği Üzerine Etkisi}

İlaç yükleme verimliğinin hesaplanmasında kullanılan ölçümleme eğrisi Şekil $4 \mathrm{a}$ ' da verilmiștir. İlaç salım profillerine göre 40, 400 ve $4000 \mu \mathrm{l}$ GA kullanılarak hazırlanan mikro kürelerin ilaç tutuklama verimlilikleri sirasiyla \%50,4 $(252,58 \pm 2,39 \mu \mathrm{g}), \quad \% 43,4(216,93 \pm 4,52 \mu \mathrm{g})$ ve \%20,6 (103,22 $\pm 0,56 \mu \mathrm{g})$ olarak hesaplanmıştır (Şekil 4b).

GA miktarı arttıkça mikro kürelerin ilaç tutuklama 


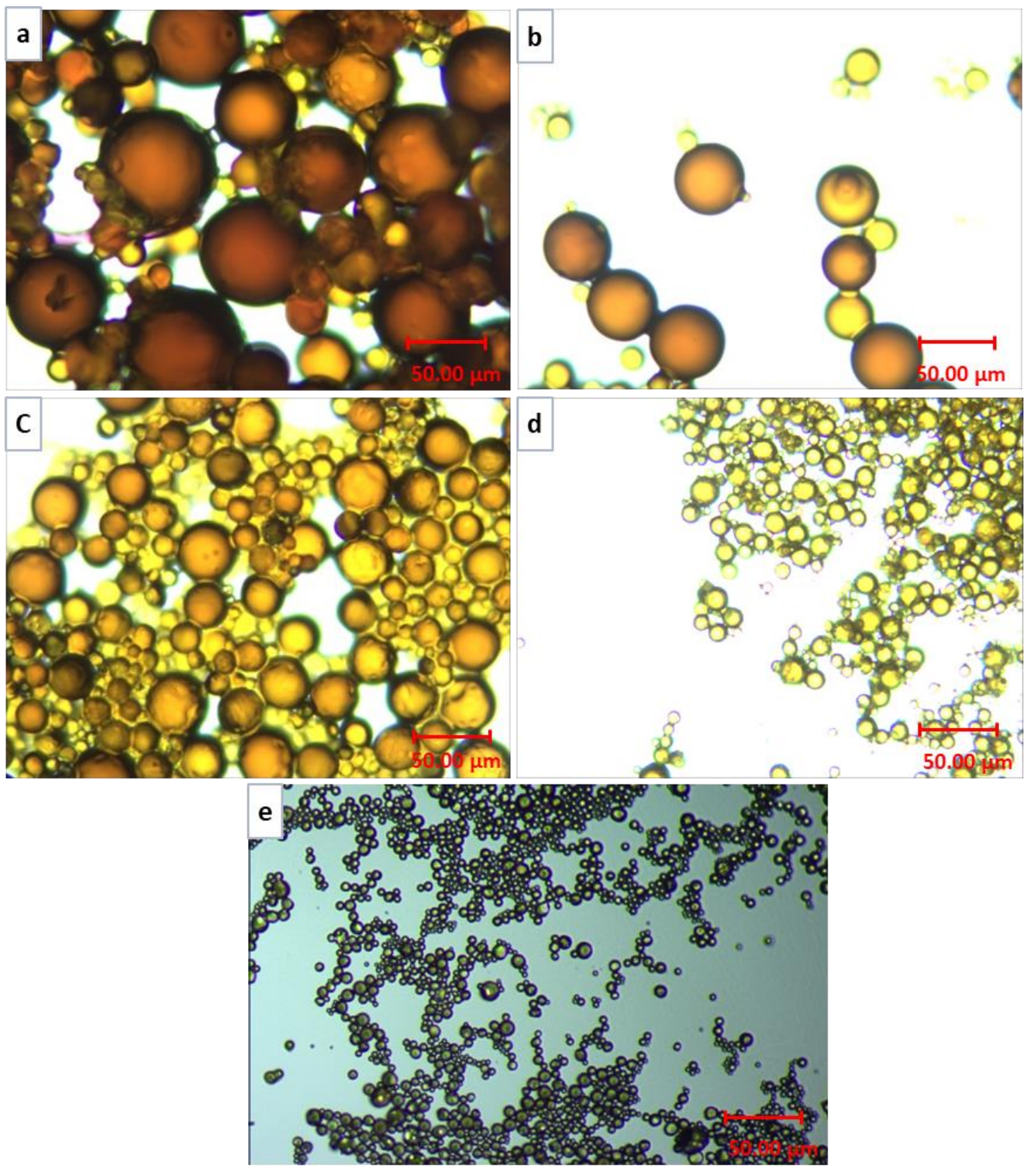

Şekil 3. Farklı karıştırma hızları kullanılarak üretilen mikro kürelerin 1şık mikroskobu görüntüleri (10x). (a) 200, (b) 300, (c) 400, (d) 500 ve (e) $600 \mathrm{rpm}$.

verimliliklerinde bir azalma olduğu görüldü. GA miktarındaki artış kürelerin boyutlarında bir azalmaya ve dolayısıyla kürelerin şişmesinde ve yüzey alanlarında küçülmeye neden olmuştur. GA miktarındaki artışın ilaç yükleme verimliliğinde düşmeye neden olmasını bu sebeplerle açıklayabiliriz.

\subsection{GA Miktarının İlaç Salım Hızına Etkisi}

İlaç yüklü mikro kürelerin 400 saatlik salım profilleri incelendiğinde, bu süre sonunda farklı GA ile üretilen mikro küreler hemen hemen tutuklanmış olan ilacın tamamını salmış durumdadır (Şekil 5a). Mikro kürelere yüklenen ilaç miktarlarına bakıldığından 40 ve $400 \mu \mathrm{l}$ GA kullanılan mikro kürelere ortalama 252 ve $216 \mu \mathrm{g}, 4000 \mu \mathrm{l}$ GA kullanılan mikro kürelere ise $103 \mu \mathrm{g}$ ilaç yüklemesi yapılmıştır.

Dolayısıyla 400 saat sonunda 40 ve $400 \mu$ l GA kullanılan kürelerden salınan ilaç miktarlarının daha fazla olması, daha az miktarda ilaç yüklenen $4000 \mu \mathrm{l}$ GA uygulanan kürelerden daha az miktarda ilaç salımının olması beklenen bir sonuçtur. Salım profilleri incelendiği zaman ilaç salım hızlarının birbirinden farklı olduğu görüldü (Şekil 5b). GA miktarındaki artışa bağlı olarak ilaç salım miktarında bir yavaşlama meydana gelmiştir.
Örneğin 40 ve $400 \mu \mathrm{l}$ GA kullanılan mikro kürelere ait 12 saatlik ilaç salım profilleri incelendiğinde; $40 \mu \mathrm{l} \mathrm{GA} \mathrm{kullanılan} \mathrm{mikro}$ kürelerdeki ilacın yaklaşık \% 89'nun (yaklaşık $225 \mu \mathrm{g}$ ) salımı

yapılmışken, $400 \mu \mathrm{l}$ GA kullanılan mikro kürelerdeki ilacın ise sadece $\% 65$ ' nin $(141 \mu \mathrm{g})$ salımı gerçekleşmiştir (Şekil 5b). GA miktarındaki artış mikro kürelerin şişmesine ve yüzey alanının azalmasına neden olmuş ilaç salımını yavaşlatmıştır. $4000 \mu \mathrm{l} \mathrm{GA}$ kullanımında ise daha fazla GA kullanılmasına rağmen daha hızlı ilaç salımı gerçekleşmiş gibi görünmektedir, çünkü grafiğe göre mikro kürelere yüklenen ilacın \%82 salınmıştır. Fakat salımı yapılan ilaç miktarına bakıldığında sadece $85 \mu \mathrm{g}$ olup, bu süre zarfında salımı yapılan en az ilaç miktarıdır.

\subsection{SBF Çalışmaları}

Mikro kürelerin SBF ile inkübe edilmeden ve edildikten sonraki SEM görüntüleri Şekil 6“ da verildi. Bu görüntülere göre inkübasyondan 1 hafta sonra mikro küre yüzeylerinde hidroksiapatit büyümesi çok az olup 2. ve 3. haftalarda ise oldukça artmıştır. Yapılan EDS analizlerinde küre yüzeylerinde oluşan çöketilerin Ca-P yapıları olduğu teyit edilmiştir (Tablo 1). 
Literatürdeki HA örneklerine ait FTIR analizlerine bakıldığında HA çökelmesini işaret eden piklerin 560, 600 ve $1046 \mathrm{~cm}^{-1}$ dolaylarında $\mathrm{PO}_{4}^{-3}$ grupları olduğu görülmektedir ( $\mathrm{Li}$ vd., 2011). $\mathrm{PO}_{4}^{-3}$ grupları 500-1500 $\mathrm{cm}^{-1}$ aralığında yer aldığından FTIR analizlerinde bu dalga boyu aralığına odaklanılmıştır (Şekil 7). Mikro kürelere ait FTIR analizlerinde HA çökelmesini işaret eden $\mathrm{PO}_{4}{ }^{-3}$ grupları 3 hafta sonunda

\section{b}

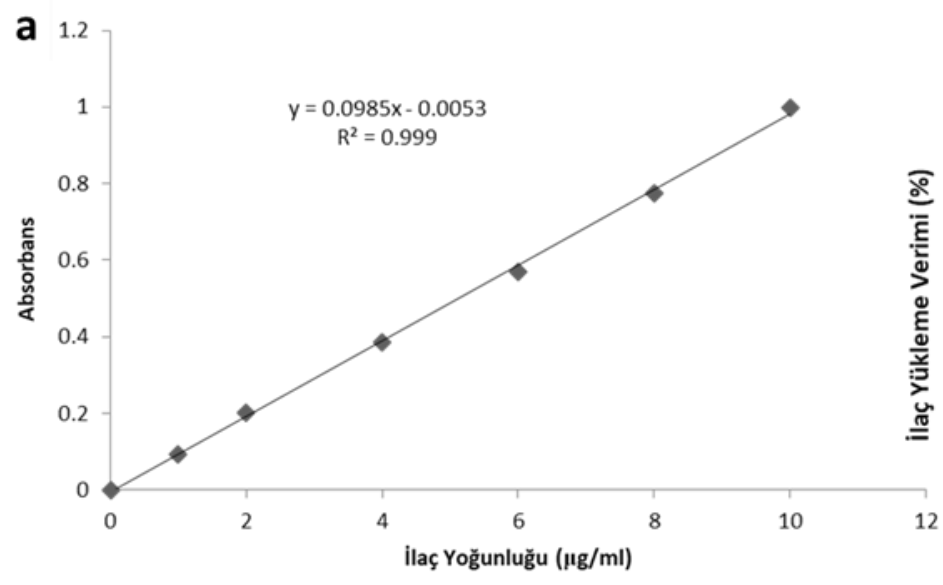

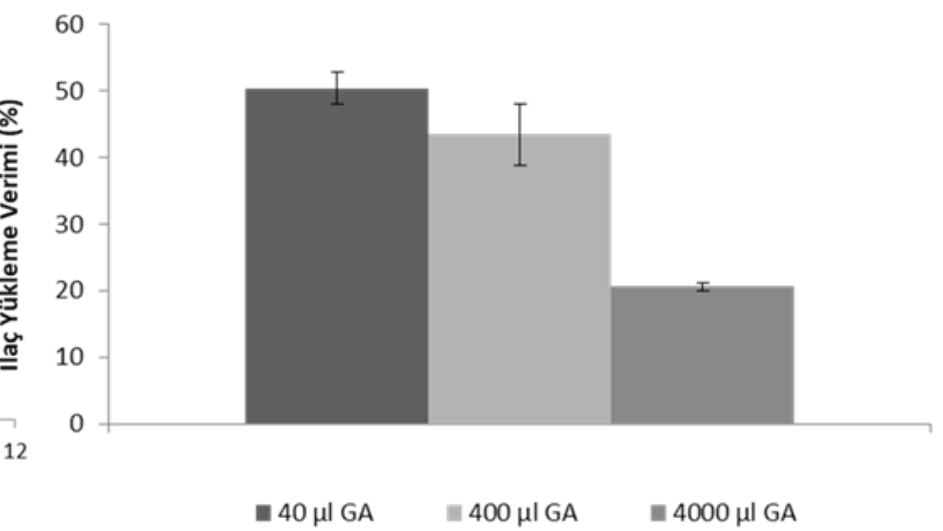

Şekil 4. (a) Kalibrasyon eğrisi ve (b) yüklenen mikro kürelerin farklı miktarda çapraz bağlayıcı kullanılması durumunda ilaç yükleme verimlilikleri (400 saat ilaç salımı sonucunda elde edilen veriler kullanılarak hesaplanmıştır).

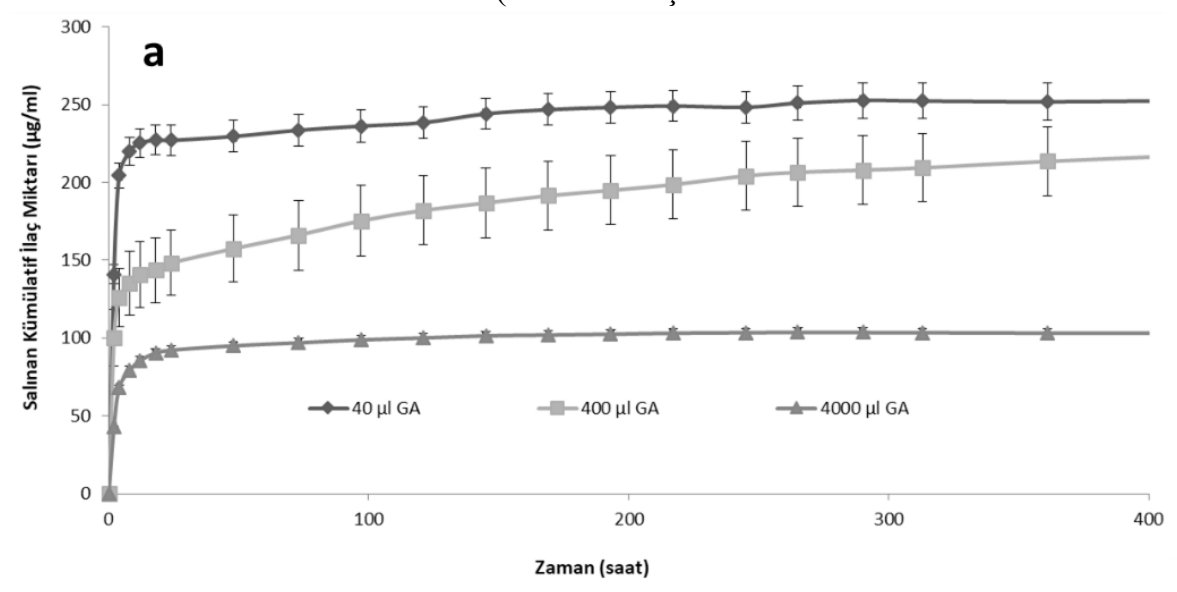

b

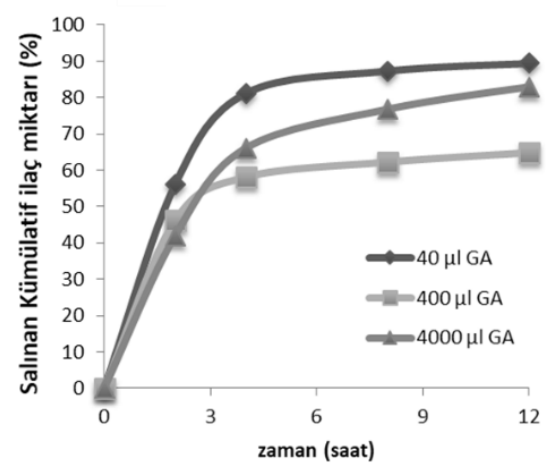

Şekil 5. İlaç yüklü mikro kürelerin (a) 400 saatlik, (b) ilk 12 saatlik (\%) ilaç salım grafikleri. 

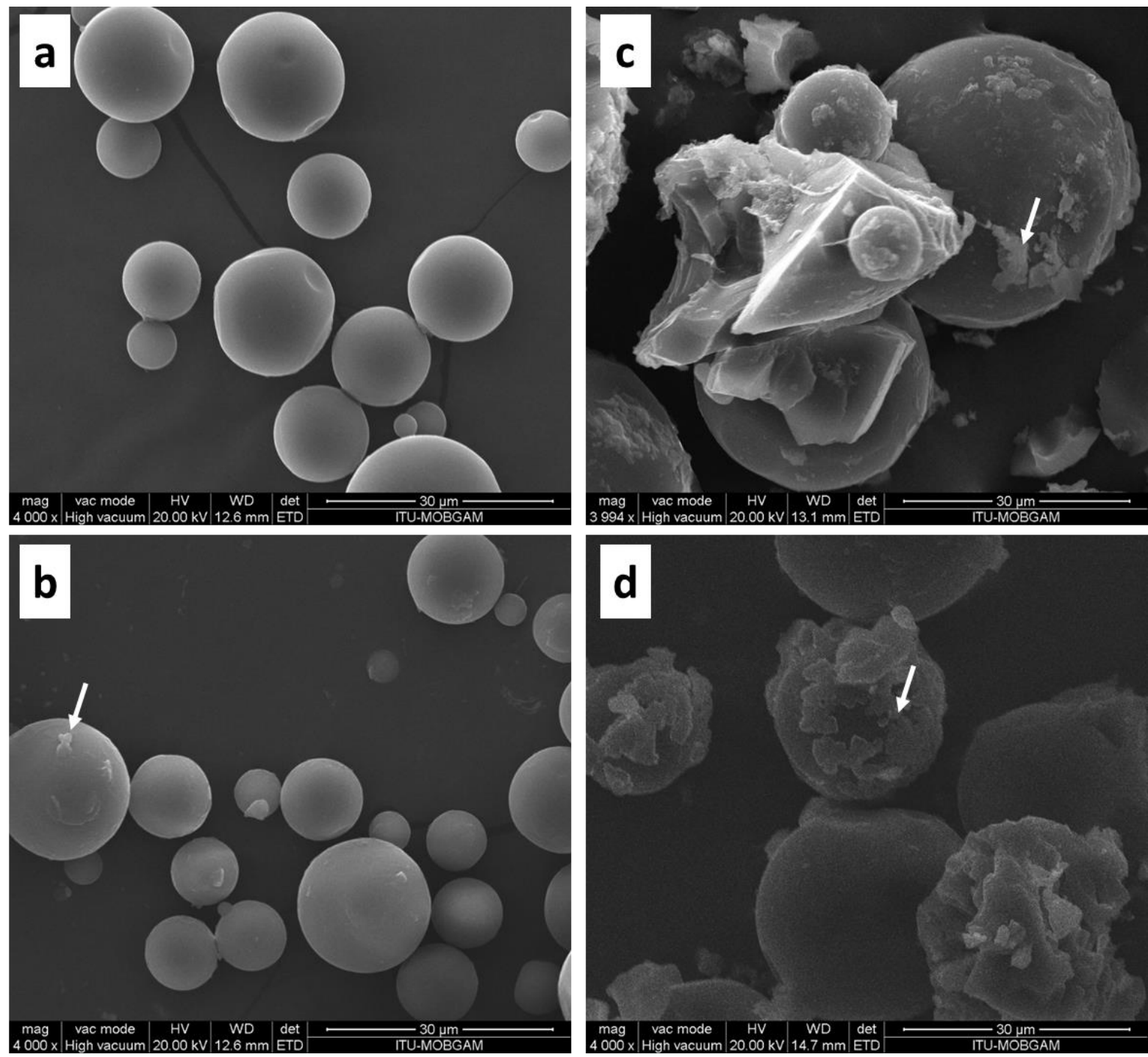

Şekil 6. Mikro kürelerin (a) $t=0$ hafta, (b) $t=1$ hafta, (c) $t=2$ hafta ve (d) $t=3$ hafta SBF içerisinde bekletildikten sonraki SEM görüntüleri (Ok işaretleri HA çökelmelerini ve EDS analizlerinin yapıldığı noktaları işaret etmektedir).

Tablo 1. Küre yüzeylerinde biriken HAyapllarına ait $C a$ ve $P$ miktarlarl

\begin{tabular}{|c|c|c|c|}
\hline Şekil & Ca ( at \%) & $\mathbf{P}$ (at \%) & Ca:P \\
\hline b & 0.5 & 0.7 & 0.7 \\
\hline c & 9.5 & 9.1 & 1.0 \\
\hline $\mathbf{d}$ & 0.3 & 0.2 & 1.5 \\
\hline
\end{tabular}

belirgin olmamakla birlikte yeni oluşmaya başlamıștır. Bu yüzeylerde $\mathrm{PO}_{4}^{-3}$ grupları $557 \mathrm{~cm}^{-1}$ dolaylarında oluşmaya başlamıştır.

HA çökelmesine ait belirgin bir $\mathrm{PO}_{4}^{-3}$ piki de $1040 \mathrm{~cm}^{-1}$ civarında bulunmakta olup kitosan kürelere ait pikler ile örtüşmektedir. Dolayısıyla HA çökelmiş yüzeylerde bu pikin direkt tespiti zor olmaktadır. Ayrıca mikro kürelere ait 3 haftalık
FTIR analizleri incelendiğinde, örneğin 996, 1058 ve $1110 \mathrm{~cm}^{-1}$ dolaylarında kitosana ait geniş piklerin HA çökelmesinden sonra daha dar bir forma dönüşmeye başladığı görüldü. Bu durumun $1040 \mathrm{~cm}^{-1}$ dolaylarındaki $\mathrm{PO}_{4}^{-3}$ grubunun varlığından kaynaklandığı değerlendirilmektedir. Kitosan mikro küre yüzeylerinde $\mathrm{HA}$ büyüme mekanizmasına bakıldığında ise, kitosanın yapısında bulunan $-\mathrm{NH}_{2}$ gruplarının ve $-\mathrm{OH}$ gruplarının HA büyümesi için çekirdeklenme merkezi oluşturdukları (Li vd., 2013) ve yüzeylerde apatit büyümesine neden oldukları düşünülmektedir. SBF çalışmasının sonuçlarına göre kitosan mikro küreler kemik dokular ile arttırılmış bir osteoentegrasyon sağlama potansiyeline sahiptir.

\section{Sonuç}

Kitosan esaslı mikro küreler emülsiyon çapraz bağlama yöntemi ile üretilmiş ve antibiyotik ciprofloxacin in vitro salım profilleri ve biyoaktiviteleri incelenmiştir. Yapılan incelemeye 


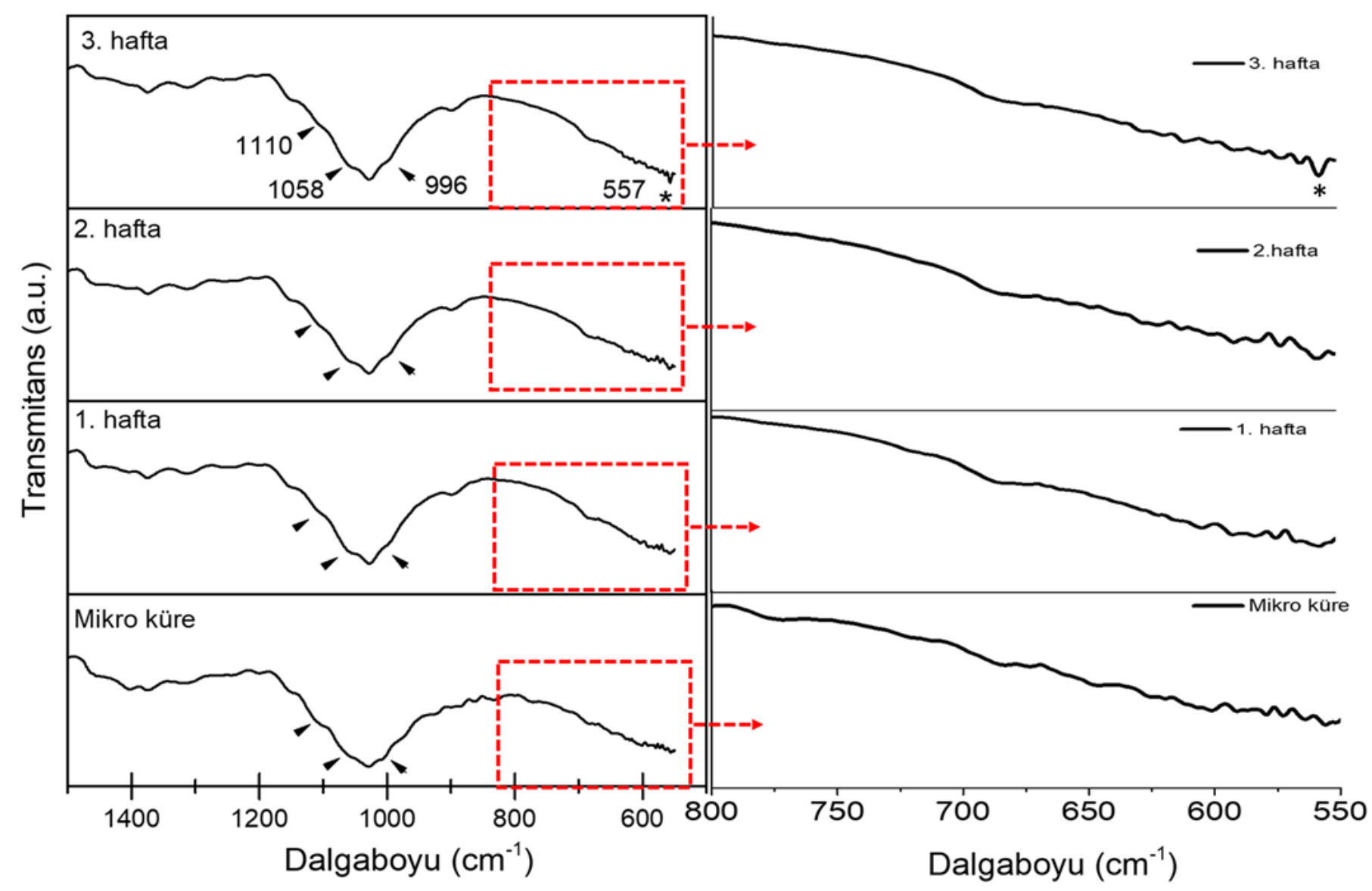

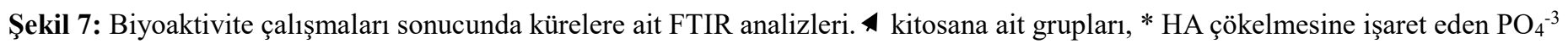
gruplarını göstermektedir.

göre karıştırma hızı ve çapraz bağlayıcı ajan üretilen mikro kürelerin şekil, boyut ve ilaç yükleme verimliliğini etkilemektedir. Karıştırma hızı ve çapraz bağlayıcı ajan GA miktarındaki artış küre boyutlarında azalmaya neden olurken, yüksek GA miktarları mikro kürelerin ilaç yükleme verimliliklerinde düşmeye ve ilaç salım hızlarında yavaşlamaya neden olmuştur. Ayrıca düşük GA kullanımı mikro kürelerin şeklinde bozulmaya neden olurken, yüksek GA kullanımında küre boyutlarının daha homojen olduğu görülmüştür. SBF içerisinde yapılan biyoaktivite testlerinde ise mikro kürelerin HA biriktirme potansiyelinin olduğu gösterilmiş olup, özellikle 3 hafta dolaylarında mikro küre HA çökelmesinin arttığ tespit edilmiştir. Bu durum SEM ve FTIR analizleri de ile doğrulanmıştır. Bu sonuçlara göre kitosan esaslı ilaç taşıma sistemleri kemik dolgu malzemesi olarak kullanılmaları durumunda osteoentegrasyonu arttırma potansiyeline sahip olabilir, hasarlı bölgenin onarılması için farklı biyomoleküllerin lokal olarak salımında kullanılabilirler.

\section{Teşekkür}

Sunulan bilgiler TÜBİTAK tarafindan deteklenen proje (proje \# 217M220) kapsamında elde edilmiştir.

\section{Kaynakça}

Agnihotri, S. A., Mallikarjuna, N. N., \& Aminabhavi, T. M. (2004). Recent advances on chitosan-based micro- and nanoparticles in drug delivery. Içinde Journal of Controlled Release (C. 100, Say1 1, ss. 5-28). https://doi.org/10.1016/j.jconrel.2004.08.010

Akbuğa, J., \& Durmaz, G. (1994). Preparation and evaluation of cross-linked chitosan microspheres containing furosemide. International Journal of Pharmaceutics, 111(3), 217-222. https://doi.org/10.1016/03785173(94)90344-1

Ali, A., \& Ahmed, S. (2018). A review on chitosan and its nanocomposites in drug delivery. Içinde International Journal of Biological Macromolecules (C. 109, ss. 273286). https://doi.org/10.1016/j.ijbiomac.2017.12.078

Bhattacharya, D., Behera, B., Sahu, S. K., Ananthakrishnan, R., Maiti, T. K., \& Pramanik, P. (2016). Design of dual stimuli responsive polymer modified magnetic nanoparticles for targeted anti-cancer drug delivery and enhanced MR imaging. New Journal of Chemistry, 40(1), 545-557. https://doi.org/10.1039/c5nj02504d

Burg, K. J. L., Porter, S., \& Kellam, J. F. (2000). Biomaterial developments for bone tissue engineering. Biomaterials, 21(23), 2347-2359. https://doi.org/10.1016/S01429612(00)00102-2

Dash, M., Chiellini, F., Ottenbrite, R. M., \& Chiellini, E. (2011). Chitosan - A versatile semi-synthetic polymer in biomedical applications. Içinde Progress in Polymer Science (Oxford) (C. 36, Say1 8, ss. 981-1014). https://doi.org/10.1016/j.progpolymsci.2011.02.001

Depan, D., Venkata Surya, P. K. C., Girase, B., \& Misra, R. D. K. (2011). Organic/inorganic hybrid network structure nanocomposite scaffolds based on grafted chitosan for tissue engineering. Acta Biomaterialia, 7(5), 2163-2175. https://doi.org/10.1016/j.actbio.2011.01.029 
Di Martino, A., Sittinger, M., \& Risbud, M. V. (2005). Chitosan: A versatile biopolymer for orthopaedic tissueengineering. Içinde Biomaterials (C. 26, Sayı 30, ss. 5983-5990). https://doi.org/10.1016/j.biomaterials.2005.03.016

Dias, K. B., Pereira Da Silva, D., Ferreira, L. A., Fidelis, R. R., Da Luz Costa, J., Lopes Da Silva, A. L., \& Scheidt, G. N. (2013). Chitin and chitosan: Characteristics, uses and production current perspectives. J. Biotec. Biodivers, 4(3), 184-191.

Filipkowska, U., \& Józwiak, T. (2013). Application of chemically-cross-linked chitosan for the removal of Reactive Black 5 and Reactive Yellow 84 dyes from aqueous solutions. Journal of Polymer Engineering, 33(8), 735-747. https://doi.org/10.1515/polyeng-20130166

Hreczuk-Hirst, D., German, L., \& Duncan, R. (2001). Dextrins as carriers for drug targeting: Reproducible succinoylation as a means to introduce pendant groups. Journal of Bioactive and Compatible Polymers, 16(5), 353-365. https://doi.org/10.1106/QBKY-E3VM-19K43GA5

Illum, L. (1998). Chitosan and its use as a pharmaceutical excipient. Içinde Pharmaceutical Research (C. 15, Sayı 9, ss. 1326-1331). https://doi.org/10.1023/A:1011929016601

Kalia, S., \& Avérous, L. (2011). Biopolymers: Biomedical and Environmental Applications. Içinde Biopolymers: Biomedical and Environmental Applications. https://doi.org/10.1002/9781118164792

Khor, E., \& Lim, L. Y. (2003). Implantable applications of chitin and chitosan. Biomaterials, 24(13), 2339-2349. https://doi.org/10.1016/S0142-9612(03)00026-7

Lee, W. K., Lee, S. M., \& Kim, H. M. (2009). Effect of surface morphology of calcium phosphate on osteoblastlike HOS cell responses. Journal of Industrial and Engineering Chemistry, 15(5), 677-682. https://doi.org/10.1016/j.jiec.2009.09.044

Leukers, B., Gülkan, H., Irsen, S. H., Milz, S., Tille, C., Schieker, M., \& Seitz, H. (2005). Hydroxyapatite scaffolds for bone tissue engineering made by 3D printing. Journal of Materials Science: Materials in Medicine, 16(12), 1121-1124. https://doi.org/10.1007/s10856-005-4716-5

Li, B., Wang, Y., Jia, D., \& Zhou, Y. (2011). Gradient structural bone-like apatite induced by chitosan hydrogel via ion assembly. Journal of Biomaterials Science, Polymer Edition, 22(4-6), 505-517. https://doi.org/10.1163/092050610X487800

Li, M., Wang, Y., Liu, Q., Li, Q., Cheng, Y., Zheng, Y., Xi, T., $\&$ Wei, S. (2013). In situ synthesis and biocompatibility of nano hydroxyapatite on pristine and chitosan functionalized graphene oxide. Journal of Materials Chemistry B, 1(4), 475-484. https://doi.org/10.1039/c2tb00053a

Liu, Y., Jiang, T., Zhou, Y., Zhang, Z., Wang, Z., Tong, H., Shen, X., \& Wang, Y. (2011). Evaluation of the attachment, proliferation, and differentiation of osteoblast on a calcium carbonate coating on titanium surface. Materials Science and Engineering C, 31(5), 1055-1061. https://doi.org/10.1016/j.msec.2011.03.003
Mattu, C., Silvestri, A., Wang, T. R., Boffito, M., Ranzato, E., Cassino, C., Ciofani, G., \& Ciardelli, G. (2016). Surfacefunctionalized polyurethane nanoparticles for targeted cancer therapy. Polymer International, 65(7), 770-779. https://doi.org/10.1002/pi.5094

Nanjwade, B. K., Singh, J., Ahmad, K., \& Manvi, F. V. (2011). Bio-pharmaceuticals: Emerging proniosomes drug delivery. Içinde Biodegradable Polymers: Processing, Degradation and Applications (ss. 639-654).

Nathan, A. J., \& Scobell, A. (2012). How China sees America. Içinde Foreign Affairs (C. 91, Sayı 5). https://doi.org/10.1017/CBO9781107415324.004

Onder, S., Calikoglu-Koyuncu, A. C., Kazmanli, K., Urgen, M., Torun Kose, G., \& Kok, F. N. (2015). Behavior of mammalian cells on magnesium substituted bare and hydroxyapatite deposited $(\mathrm{Ti}, \mathrm{Mg}) \mathrm{N}$ coatings. New Biotechnology, 32(6), 747-755. https://doi.org/10.1016/j.nbt.2014.11.006

Onder, S., Kok, F. N., Kazmanli, K., \& Urgen, M. (2013). Magnesium substituted hydroxyapatite formation on (Ti, Mg)N coatings produced by cathodic arc PVD technique. Materials Science and Engineering C, 33(7), 4337-4342. https://doi.org/10.1016/j.msec.2013.06.027

Pasinli, A., \& Aksoy, R. S. (2010). Yapay Kemik Uygulamaları İçin Hidroksiapatit Hydroxyapatite For Artificial Bone Applications. Xxx, 2010(1), 41-51.

Şenel, S., \& McClure, S. J. (2004). Potential applications of chitosan in veterinary medicine. Advanced Drug Delivery Reviews, 56(10), 1467-1480. https://doi.org/10.1016/j.addr.2004.02.007

Seyfoddin, A., \& Al-Kassas, R. (2011). Biodegradable polymers for controlled delivery of bioactive macromolecules. Içinde Biodegradable Polymers: Processing, Degradation and Applications (ss. 471-500).

Sinha, V. R., Singla, A. K., Wadhawan, S., Kaushik, R., Kumria, R., Bansal, K., \& Dhawan, S. (2004). Chitosan microspheres as a potential carrier for drugs. Içinde International Journal of Pharmaceutics (C. 274, Sayılar 1-2, $\quad$ ss. $1-33)$ https://doi.org/10.1016/j.ijpharm.2003.12.026

Teixeira, S., Rodriguez, M. A., Pena, P., De Aza, A. H., De Aza, S., Ferraz, M. P., \& Monteiro, F. J. (2009). Physical characterization of hydroxyapatite porous scaffolds for tissue engineering. Materials Science and Engineering $C$, 29(5), $1510-1514$. https://doi.org/10.1016/j.msec.2008.09.052

Thanou, M., Verhoef, J. C., \& Junginger, H. E. (2001). Oral drug absorption enhancement by chitosan and its derivatives. Içinde Advanced Drug Delivery Reviews (C. 52, Say1 2, ss. 117-126). https://doi.org/10.1016/S0169409X(01)00231-9

Wedmore, I., McManus, J. G., Pusateri, A. E., \& Holcomb, J. B. (2006). A special report on the chitosan-based hemostatic dressing: Experience in current combat operations. Journal of Trauma - Injury, Infection and Critical Care, 60(3), 655-658. https://doi.org/10.1097/01.ta.0000199392.91772.44

Zhe, Z., Zhang, S., Venkatraman, S. S., \& Lei, S. (2011). Growth of hydroxyapatite coating on polymer microspheres. Nanoscience and Nanotechnology Letters, 3(4), 472-476. https://doi.org/10.1166/nnl.2011.1204 